\title{
GESKIEDENIS VAN DIE PREDIKING IN SUID-AFRIKA
}

\section{DS. J. C. DE LANGE}

\section{Inleidende Opmerkings:}

Hierdie lesing kan nie in die volle sin van die woord 'n wetenskaplike lesing genoem word nie, omdat:

a. Die preke wat deur die jare heen gehou is, baie selde gepubliseer is. Alleen enkele predikante het preke gepubliseer en in die ondersoek kon alleen gepubliseerde preke geraadpleeg word. Die ondersoek gee dus nie 'n volledige beeld nie.

b. Die predikante wat wel preke gepubliseer het, het normaalweg nie alle preke wat hulle gelewer het, op skrif gestel of gepubliseer nie.

c. Van die bestaande gepubliseerde preke is ook nie almal deurgewerk nie - veral nie die preke van die vir ons minder bekende Kerke soos bv. die Engelse, Lutherse, Rooms-Katolieke Kerke en sektariese strominge nie.

d. Voorts is 'n geskiedenis van die prediking 'n weergawe van besondere kenmerke wat sig in die prediking openbaar, eerder as die beskrywing van historiese gebeurtenisse op bepaalde tye.

e. Wanneer in die lesing ook bepaalde kenmerke in die prediking behandel word, is daardie kenmerke subjektief gekies en behandel. 'n Blote objektiewe stelling van historiese feite, as daar so iets kan bestaan, kan hierdie lesing in elk geval beslis nie wees nie.

\section{Europese Gebondenheid:}

Die volksplanters het in 1652 aan die Kaap gekom met bepaalde kenmerke wat gekoppel was aan hulle godsdiens en prediking. Ons vadere het nie uit die lug geval nie. Ons kan veral vier belangrike feite in hierdie verband noem:

1. Hulle het hier gekom met die Statebybel met sy kantaantekeninge waaruit die Skrifverklaring geneem is. Die Bybel neem vandag nog 'n sentrale plek in op alle kansels. Hierdie Woord van God is die bron van die prediking.

2. Ons vadere het hier gekom ná die en as gevolg van die Hervorming. Die Calvinisme het insonderheid 'n onuitwisbare stempel afgedruk op die prediking van predikante in Suid-Afrika. 
3. Prediking en Skrifverklaring is gehou in ooreenstemming met die drie Formuliere van Enigheid, nl. die Nederlandse Geloofsbelydenis (1561), die Heidelbergse Kategismus (1563) en die Dordtse Leerreëls (1618/19).

4. Dit moet ook in gedagte gehou word dat Suid-Afrika baie jare sy predikante uit Europa gekry het. Daar is hulle opgelei. Die opleiding van eie predikante in Suid-Afrika dateer te Stellenbosch vanaf 1859, te Burgersdorp vanaf 1869, te Potchefstroom vanaf 1904, te Pretoria Afdeling A, vanaf 1917, Afdeling B vanaf 1938. Die professore wat hierdie opleiding aanvanklik behartig het, is ook in Europa opgelei, sodat die Europese invloed nog baie jare na die selfstandige opleiding deurwerk.

Die Europese gebondenheid van die Engelssprekende Kerke is nog groter. Joost de Blank stel dit in 1964 so: "Only two of our bishops are South Africans born and bred". Hy verwys dan na biskop Burnett van Bloemfontein en assistent biskop Alhpaeus Zulu.

\section{BESONDERE KENMERKE VAN DIE PREDIKING:}

\section{Tekskeuse:}

Calvyn het hom nie altyd aan 'n bepaalde teks gebind in sy prediking nie. Hy het eenvoudig van die een vers na die ander vers oorgegaan. Sy doel in die prediking was om die Skrif uit te lê en die Skrif te laat ken. By die deurgaande behandeling van die stof het hy ook nie gelet op die kerklike jaar nie. Hy gaan gewoon deur met die behandeling van opvolgende stof. Daarom hou hy 'n serie preke oor die hele boek Deuteronomium, Job, die Evangelies, ens. Uit Deuteronomium hou hy 200 preke. Zwingli het ook die gebruik gehad om in elke preek kortliks te herhaal wat hy in die voriges gesê het, om sy hoorders met die samehang van die Christelike leer vertroud te maak.

Hierdie metode nl. om bloot opvolgende stof te behandel, vind ons ook by vroeëre predikante in Suid-Afrika. Voorbeeld hiervan is die behandeling van die geskiedenis van die Emmausgangers (Luk. 25:15 v.v.) deur ds. M. J. Goddefroy. Serie-preke uit verskillende Bybel-boeke word af en toe vandag nog gehou. Die oorgrote meerderheid egter word aan die hand van 'n gedeelte van 'n vers, 'n enkele vers of 'n paar verse saam, gehou.

Suid-Afrikaanse predikante bind hulle by hulle tekskeuse van vroeg af reeds aan die kerklike jaar. Uit die pen van ds. J. 
Murray (1891) het ons 'n 27 tal geleentheidspreke vir Kersfees, Lydenstyd en ander kerklike feesdae.

Uit die tekse waaroor daar gepreek is, blyk dit dat die predikante min of meer net so dikwels uit die Ou Testament as uit die Nuwe Testament gepreek het.

\section{Skemas van die preke:}

Die leerredes van vroeër jare het 'n bepaalde patroon gevolg. Dit het in die reël bestaan uit drie afdelings.

a. 'n Voorafspraak en inleiding.

b. Verklaring van die teks.

c. Toepassing.

Tussen die voorafspraak en die verklaring van die teks, is meermale 'n Psalm of Gesing gesing. Voor die toepassing is ook soms gesing.

Terwyl dit baie opsigtelik is dat die predikante hulle leerredes sorgvuldig aan die hand van 'n skema opgestel het, is dit ewe-eens duidelik dat hierdie skemas baie uitgebreid geraak het.

Ds. D. Postma se skema as „lijkrede op het overlijden van onze Grietjie oud 12 jare", het as volg daaruit gesien:

Voorafspraak: Sing Ps. 89:1,3.

Inleiding: $1,2,3,4$.

Verklaring: I : 1, 2, 3. a.b.c.d.

II $: 1,2$.

III : $1,2$.

IV : $1,2$.

Toepassing: $1,2,3,4,5,6,7,8,9$.

Predikante was voorts lief daarvoor om die voorafspraak of die inleiding te laat uitloop op 'n opsomming van die stof wat verder aan in die preek behandel gaan word. Tipiese voorbeeld hiervan is ' $n$ preek van ds. J. Murray oor Ps. 51:8 waarvan die inleiding uitloop op:

„De volgende bijzonderheden zullen thans onze aandacht bezig houden.

Vooreerst: waarheid in het binneste veronderstelt de kennis der waarheid met het verstand.

Vervolgens: waarheid in het binneste bestaat in de opregtheid van hart voor God. 
Eindelijk: waarheid in het binneste word bewezen door eerlijkheid, waarheid in den wandel".

Preke bestaan hoofsaaklik nog altyd uit 'n skema van: Inleiding, Eksegese en toepassing. Meermale word die toepassing algaande gemaak. Ons kry egter die gebruik teenswoordig om 'n preek in 'n opstelvorm te skryf, waarin die gedagtes en onderafdelings meer soepel in mekaar invloei en aansluit. In die preke van vroeëre predikante mis ons een sentrale gedagte of boodskap. Die leerredes is te analities van aard en te weinig sinteties, daarom maak die leerredes normaalweg ' $n$ lomp indruk.

\section{Inhoud van die prediking:}

Onderwerpe waaroor gepreek word is baie uiteenlopend van aard, en dek enige onderwerp wat uit die Skrif of die geskiedenis of die hede na vore gebring kan word.

In die prediking van Suid-Afrikaanse predikante word die soewereiniteit van God sterk beklemtoon. God is die Heer van alle dinge en Hy beskik en bestuur. Ons mense het die verantwoordelikheid om te dien en te gehoorsaam. Ons volk is hier deur God geplant en elkeen se lotgevalle is in die hande van die Skepper.

Die prediking van Jesus, veral sy gelykenisse en die wonderwerke deur Hom verrig, is die tema in talle van preke. Die verlossingswerk deur Jesus Christus vir Sondaars voldaan, is die onderwerp van die meeste preke, en die grootste persentasie preke loop daarop uit, as dit nie die onderwerp is nie.

By sekere geleenthede, soos Pinksterfees, voorstelling van lidmate, ens, handel die preke oor die Heilige Gees. Die sektariese strominge maak in hulle prediking meer van die Heilige Gees.

Verskillende leerstukke van die Kerk word ook behandel, bv. die uitverkiesing, die regverdigmaking, die Drie-eenheid van God, ens. Die Lutherane stel hulle dit veral ten doel om in die Skrif te soek na die argumente wat die meeste gunstig is om die vernaamste punte van hulle dogmatiek te bewys. Ons kan dit selfs as 'n beswaar teen preke van vroeëre predikante inbring dat hulle te dogmaties gepreek het en dat die teks dikwels gebruik word as 'n middel om daardeur dogmatiese waarhede te kan uitstal.

Wanneer 'n preek 'n dogmatiese waarheid wil verdedig, word dit meermale ' $n$ felle aanval op andersdenkendes. Ds. S. J. du 
Toit se prediking was veral 'n pleidooi vir die gereformeerde waarhede. Soms het 'n preek van hom net bestaan uit die toeligting van een of ander leerstuk, soms was dit 'n samevatting van die vernaamste leerstukke. Hy beskou die leerstuk oor die predestinasie as die hart van die Kerk en die tweede grondswil waarop die gereformeerde waarheid gebou is, die Verbondsleer. Vergelyk sy preek oor Simson (Rigters 16:22).

Tydens die Sinode van Dordrecht in $1618 / 19$ is reeds gekla oor die groot onkunde ten opsigte van die leer van die Kerk. Veral is aangedring op gereelde kategetiese prediking uit die Heidelbergse Kategismus. Die suiwerheid van leer is baie hoog gewaardeer en ketterye in allerlei vorme is terselfdertyd bygehaal en aan die kaak gestel. Die handhawing en verdediging van die leer van die Kerk is in die 17 de eeu baie op gelet. Preke uit daardie tyd is sterk dogmaties gekleurd en suiwer in leer.

Die diepe verderf waarin die mens lewe, kom voortdurend ter sprake. In kleurryke taal word dit gestel.

Daarby aansluitend word die vernuwing van die mens behandel; óf as die werk van ander mense óf as die werk van die persoon self en daar ook óf langs ' $n$ baie lang weg van beproewing of deur 'n skielike en momentele bekering.

Oor die Kerk as liggaam van Christus word voortdurend gehandel. Hier kan ons die preek van ds. M. J. Goddefroy aanhaal wat hy gehou het by die ingebruikneming van die nuwe kerkgebou te Bronkhorstspruit op 12 April 1913 waarin hy na Witfontein gemeente verwys as die ark van die Nederduitsch Hervormde Kerk; die afskeidspreek van ds. F. C. Cachet te Utrecht oor Filippense II:16, en die afskeidspreek van ds. J. J. Kotze te Darling oor I Joh. II:28.

Dit lyk egter asof vroeëre predikante nie so baie oor die kerk gepreek het nie, as predikante van 'n later datum. Preke van ouer predikante het meer die wekroep: „Kom na die Here Jesus".- Preke van 'n jonger datum het meer die wekroep: „Kom na die Kerk".

Prediking oor die onvervulde profesië is skaars. Weinig predikante handel hieroor. Ds. S. J. du Toit het \pm 1878 'n reeks preke gelewer omdat hy voel dat daar 'n leemte by die Reformatore en die predikante bestaan met betrekking tot die leer van die laaste dinge. 


\section{Die toepassing van preke:}

Die toepassings wat gemaak word in die preke is ewe-eens baie wyd uiteenlopend. Christusverkondiging en Skrifverklaring lyk my egter staan voorop. Dit is die doel van die prediking en daarom vind ons ook Christusverkondiging en Skrifverklaring in die toepassings gestel. Die middelpunt waaromheen die gemeente sig skaar, is die kansel, op die kansel lê die Bybel die Woord van God. Om hierdie Woord te hoor, daarvoor kom die gemeente na die Kerk en luister hulle na die prediking. Teenoor die EREDIENS by die Rooms-Katolieke Kerk staan die LEERDIENS van die gereformeerde godsdiens. Die protestantse gemeente word nie geroer, oorweldig en meegesleep deur die mag van musiek, prag van klere, mistieke werking van simboliek en liturgie nie, maar deur die skrifverklaring, die woord, die vleesgeworde Woord. Prof. S. D. van Veen stel dit so: „De Roomse gaan naar de Mis, de Gereformeerden gaan naar de preek".

Met die prediking is beoog om die gemeente die Bybel te laat ken. Dit is duidelik dat die predikante van die veronderstelling uitgegaan het, dat die gemeentelede die Bybelse geskiedenis ken. Veral wanneer hulle die Skrif vanuit die Skrif verklaar is selfs moeilike geskiedenisse ter illustrasie gebruik, dikwels sonder verdere omskrywing omdat die geskiedenis blykbaar by die gemeentelede bekend was. Vergelyk 'n preek van ds. J. Murray oor Matt. 27:46 „My God, My God, waarom het U My verlaat?” waar hy hierdie bekende kruiswoord van Jesus illustreer met die aanhaal van die geskiedenisse van Job en Bozra.

In die toepassings het daar 'n baie sterk trooswoord opge. klink. Na my oortuiging was die vertroosting sterker beklemtoon deur die ouer predikante. In hierdie verband word die verbondsgedagte in die Bybel, die versoeningswerk van Jesus, Sy lyding en die geskiedenis van Job baie gebruik. Daaruit word die vertroostende boodskappe veral geput.

Moraalpredikers in die egte gesonde sin van die woord en ook in die slegte $\sin$ van die woord is daar baie. Die gehoorsaamheid word as besondere deug van die Christen gestel. Wekroepe om te luister na en te leef volgens die Wet van God klink helder op. Prof. J. du Plessis het sy gemeentelede uitgenooi om op 'n kaartjie vir hom te skryf wat die kerkbank van die kansel verwag. Uit antwoorde van sy korrespondente was dit opvallend dat die meeste van hulle prediking oor die sonde nodig geag het - die wese daarvan, die bestryding daarvan en die oorwinning daarvan. Hy het dan ook die eis gestel dat die prediking 'n meer sedelike strekking moet hê en met alledaagse 
misstande in verband gebring moet word.

Prof. P. J. G. de Vos het op 'n predikante konferensie te Middelburg, Transvaal, die aanwesiges opgewek om in hul prediking beslis ' $n$ sedelike doel te beoog. Om leerstellig te preek, was sy standpunt, is nie so moeilik nie, maar om een of ander persoonlike sonde of maatskaplike kwaad te bestraf, eis baie moed. Die gebrek aan hierdie moed sou veroorsaak dat preke in algemeenhede verval en die indiwiduele sondes verby gegaan word. Prof. J. I. Marais het hom herhaaldelik in hierdie gees uitgelaat.

Dit kan gesê word dat die Ned. Geref. Kerk deur die jare 'n eie stempel op sy preekwyse afgedruk het. Die leerredes van voorheen is onder invloed van mense soos di. Van Lier en M. C. Vos reeds teen die einde van die 18de eeu vervang met 'n meer evangeliese skrifuitleg met sy toepassing op die eie toestande en behoeftes.

Preke van baie predikante het egter ontaard in moraalverkondiging.

Bestraffinge, bestryding van dwalinge van die tyd en aanvalle op besondere toestande wat onder mense heers, kom in die toepassings voor. Uit 'n preek van ds. M. J. Goddefroy kom as voorbeeld hierdie opmerking: „En toen indertijd na die eerste Engelse oorlog, Konsiliatie en ko-operatie in de lucht zweefden met het oog op de verschillende hollandsprekende Kerke . . . . Daarbij, het is nu eenmaal een dwaling, en een Rooms begrip, als zou de toekomst en het heil van Land of Kerk zijn gelegen in uitwendige samesmelting van verschillende Kerken en sekten".

Aanvalle teen staatkundige partye, soos die volgende kom meermale voor. In 'n preek van Joost de Blank lees ek: „Monday, March 21st 1960, was South Africa's black Monday. On that day the simmering pot of interracial conflict came to the boil, and both at Sharpeville in Johannesburg and at Langa in Capetown the police fired on crowds of Africans gathered to protest against the pass laws of the country and many casualties resulted."

Dr. G. D. J. Schotel stel hierdie feite baie jare voor Joost de Blank as volg: „Veral in die laaste van de 16de en begin van de $17 \mathrm{de}$ eeu het predikante stoutweg sonder moderatie de politie en regering, niet alleen van den lande maar ook van uitheemse, zelfs bevrinde potentaten op den stoel bragten, en zonder aanzien des persoons hooge en lage regimenten, koningen en prinzen berispten ..."

Vurig word die een of ander volksleier of volk vergelyk met 'n heidense volk of volksleier uit die Bybel. Meermale word 
die Suid-Afrikaanse volk vergelyk met Israel van ouds. Vergelyk hier veral preke van dr. C. R. Kotze en ds. G. J. J. Boshoff.

\section{BESONDERE SAKE WAT DIE PREDIKING BEİNVLOED HET}

\section{Sending :}

Die end van die 18de eeu was die geboortetyd van die moderne sendingywer. Die Europese volke het hulle pligte teenoor die onbeskaafde nasies gevoel en een gevolg daarvan was die begeerte om die lig van die Evangelie aan die heidene te bring. Die invloed van hierdie nuwe gees het spoedig ook SuidAfrika bereik en hiervoor was ds. H. R. van Lier verantwoordelik. $\mathrm{Hy}$ is in $\mathbf{1 7 8 6}$ as predikant van Kaapstad aangestel. Dit het hom gegrief dat daar so weinig gedoen was om die Hottentotte te bekeer en het alles in sy vermoë gedoen om belangstelling in die sending op te wek.

In Kaapstad het hy 'n kring van sendingvriende om hom versamel en die omliggende gemeentes het ook hierdie invloed gevoel.

Ds. Van Lier word kort na sy dood opgevolg deur ds. M. C. Vos, wat in 1794 sy intreerede hou oor Markus 16:15 en 16: "Gaan die hele wêreld in en verkondig die evangelie aan die ganse mensdom ..." Prof. Du Plessis noem ds. Vos : „The man who above all, deserves the honour of being considered the pioneer of the missionary spirit in South Africa."

In 1792 het drie Herrnhutters en in 1799 het 'n paar sendelinge van die Londense Sendinggenootskap in Suid-Afrika kom arbei. In 1799 is die S.A. Sendinggenootskap gestig.

Hiermee is die weg gebaan vir baie preke wat oor die sending sou handel. Hieraan neem alle kerke deel, al verskil die metode wat die kerke aanwend om die heidene te kersten soms hemelsbreed. Uit die talle van preke wat hieroor handel noem ek 'n preek van dr. J. A. Schutte oor Hand. $16: 9$. „Kom oor na Macedonië en help ons".

\section{Die Metodisme :}

Die werk en prediking van Wesley (1703-1791) en Whitefield (1714-1770) het 'n groot uitwerking gehad op die predikang in Suid-Afrika. Vir Whitefield was die berg die beste preekstoel en die hemel die beste klankbord. Toe die kansels vir Wesley versper is, het hy weer 'n gehoor gesoek in verenigings en geselskappe en verklaar dat hy in die "Foundery-society" wat 
hyself gestig het, die suiwerste analogie van die apostoliese kerke sien.

Hulle wou albei egter harte, siele, ja die wêreld met hulle mond verower.

Die karakteristieke van die metodistiese prediking is om die bekering as 'n abrupte breek met die voorafgaande voor te stel. Belangrik vir die metodiste is die metode van bekering. Tog is hierdie metode, hoe belangrik ook al vir hulle, nie in sy volle omvang beskryf nie. Traktate bevat alleen aanwysinge wat betrekking het op die metodiek van bokering.

Die metodistiese leer in sy oorweldigende ywer om siele te win, sien as volg daaruit :

1. Teen die hele wêreld, as synde heidendom, word oorlog verklaar.

2. Hierdie heidene word met boeteprediking aangeval.

3. Daarna word op die indiwidu toegespits.

4. Die verowerde indiwidu word in sy geledere geïnkorporeer.

Gedurende die eerste helfte van die negentiende eeu is daar aanwysings dat die Ned. Geref. Kerk begin wegkom van 'n tradisionele weg en 'n eie karakter ontwikkel ten opsigte van die aanwending van middels waardeur die geestelike lewe van sy lidmate versterk en verdiep kan word, asook om aan die lidmate 'n groter aandeel te gee in die godsdiensaefeninge.

Daar is onder invloed van die metodisme begin met spesiale evangelieprediking. Die Sinode van 1876 het besluit: „Met het oog op spesiale Evangelieprediking op plaatsen waar die wordt verlangd, word eene Commissie door deze H.E. vergadering benoemd, ten einde aanzoeken van leeraren en kerkeraden te ontvangen en leeraren tot dat werk onder hare regeling uit te noodigen." Ds. Van Velden het hierop gewaarsku dat die voorheeld van Amerika hiermee nagevalg word. Die voorstel is egter aangeneem en die weg is gebaan vir spesiale evangelieprediking. Daar is van die dienste van dr. Andrew Murray en dr. S. Hofmeyr gebruik gemaak. Dit was egter eers in 1930 dat ds. Jac van der Merwe aangestel is as 'n spesiale evangelieprediker.

In hierdie spesiale evangelieprediking word die invloed van die metodisme ontdek in die metode wat by die dienste gevolg word. Aangesien dit die prediker se spesifieke doel is om siele te win, handel hy aanvanklik oor die sonde in al sy doemlikheid en dan word daar by die hoorders aangedring op 'n onmiddellike 
bekering. By die metodisme is dit dié metode waarop die bekering plaasvind, $n l$. 'n plotselinge krisis, 'n heftige emosie en 'n bewuste ommeswaai wat die skyn wek asof die mens gered word, „by conversion rather than by Christ". In teenstelling met die piëtisme wat meen dat die bekering slegs deur 'n geweldige stryd teweeggebring kan word, laat die metodisme die klem val op die onmiddellikheid van die bekering. Die doel en metode van die metodisme plaas die mens en nie God nie, op die voorgrond en gee aan die mens die keuse om salig te word.

Die praktyk wat beoefen word met die spesiale evangelieprediking is ook opvallend. Die prediker sal byvoorbeeld die gehoor in stil gebed laat verkeer en dan sal hy vra of daar iemand is wat sy hart aan die Here wil gee. Indien daar iemand is, moet hy sy hand opsteek. Dan wag die prediker vir 'n oomblik. Niemand steek sy hand op nie. Hy versoek die gemeente weer om dit te oorweeg en dan hande op te steek as 'n bewys dat hulle die Here Jesus wil dien. Dan steek daar een die hand op. In ekstase roep die prediker uit: „Daar is een! Prys die Here daarvoor! Kom, wie is daar meer? Ja, daar is nog een en nog een."

Of die prediker, toe hy 'n gesangvers laat sing, versoek die gemeente, dat alleen diegene wat die Here Jesus lief het, moet opstaan om die vers te sing. Nadat die vers gesing is, het hy diegene wat gesing het, versoek om die gebou te verlaat en die wat nie gesing het nie, moes agterbly. Soms word selfs afgekondig dat by opvolgende dienste, al die onbekeerdes aan die linkerkant en al die bekeerdes aan die regterkant van die preekstoel moet sit.

Let op die volgende voorbeeld uit 'n preek van ds. P. W. Marais.

,Jy sal weet dat God $u$ siel gered het en dat $u$ van nou af 'n kind van die Here is. Die vier stappe:

(a) Bely en erken dat $u$ verlore is;

(b) Bely u sondes aan God met die voorneme om reg te maak wat u verbrou het;

(c) Neem Jesus Christus aan as die Draer van u sondes;

(d) Vertel dit aan God met $\mathbf{u}$ mond. Vat hom op sy Woord dat $\mathrm{Hy} u$ siel gered het en vertel nou aan $\mathrm{u}$ vriende en môre op kantoor God het my siel gered ... .

Doen nou die volgende gebed. Ek sal dit eers vir u sê. Here ek bely ek is ' $n$ verlore sondaar, vergewe my al my sondes; help 
my om die prys te betaal .. Doen nou die gebed net waar u is."

By sulke spesiale dienste word baie pressie uitgeoefen op die lidmate om getuienis af te lê en dat die gedagte gesuggereer word dat slegs hulle wat getuienis aflê, opregte kinders van God is. Predikers meet die seën op hulle prediking aan die aantal getuienisse wat afgelê word. Die kerklied word baie gebruik om krag by die gevoelsprediking te voeg. Sulke opwekkingsliedere het egter meermale 'n inhoud wat nie Skriftuurlik is nie.

\section{Bidure en Prediking oor die Heilige Gees :}

Bidure was gedurende die eerste $1 \frac{1}{2}$ eeu na die volksplanting feitlik onbekend. Daarna het bidure geleidelik ontstaan en vanaf plus-minus 1830 het die gebruik algemeen geword. Die ontstaan van bidure het nou saamgehang met die geesdrif vir sending.

Op aandrang van 'n dieper geestelike lewe en 'n warme belangstelling in sendingwerksaamhede word daar onder leiding van dr. H. R. van Lier in 1778 in Kaapstad 'n bid- en werkvereniging gevorm met die doel om die Kleurlinge en slawe in die praktiese Christendom te onderrig. Toe die sendelinge van die Londense Sendinggenootskap aan die einde van die 18de eeu na Suid-Afrika gestuur is en in die belang van die sending 'n Suid-Afrikaanse genootskap in Kaapstad in 1779 gestig is, word daar ook 'n maandelikse biduur ingestel.

Dit is opvallend dat die bidure in die grensgemeentes posgevat het. Blykbaar het dié gemeentes, omring van gevare, behoefte daaraan gevoel om in die gebed saam te kom.

Die bidure is verbind aan die begeerte na herlewing of 'n dieper geestelike lewe en die uitstorting van die Heilige Gees. Dit was 'n gesindheid wat vanuit die buiteland oorgekom het.

De Gereformeerde Kerkbode publiseer met insteming berigte oor die opwekkinge. Ds. Van der Lingen wys veral op die geluk wat die geloofsgenote in Noord-Amerika in hierdie opsig het bokant hulleself hier in Suid-Afrika.

In 1860 nooi proff. Hofmeyr en Murray en ds. J. H. Neethling belangstellendes uit na 'n konferensie te Worcester. Die vernaamste onderwerp was: „Herlewing”. En vanaf 1861 hou ds. Van der Lingen van Paarl tien dae voor Pinkster Sondag die sogenaamde pinkster-bidure.

Prediking by sulke geleenthede is gewoonlik vurig van aard. 
Vergelyk hier die werk van sendeling Hofmeyr vanaf 1875 in Zoutpansberg, bv. die avondmaalsdiens op Sondag 14 Mei 1876 oor Hooglied 2:16. Oor wat na die diens gebeur het, verhaal Hofmeyr as volg: „Er ware voetpaden oopgetrapt door bekommerde bidders naar bosschen, sloten, enz." Die prediking van sektatiërs oor die Heilige Gees is dikwels ook van so 'n aard, dat dit uitsonderlike dinge tot gevolg het.

\section{Sektariese Strominge :}

Verskillende sektariese strominge is veral na 1900 in SuidAfrika vanuit die buiteland oorgeplant. Ons gee in die lesing nie 'n oorsig van hierdie verskillende groepe nis. Die volgende algemene kenmerke in sektariese prediking word gestel:

(a) Prediking van die sektes is 'n reaksie teen die Kerk, ampsdraers en leer van die Kerk waarteen hulle hul rig. Die anti-kerklike houding van die sektariër is onmiskenbaar in hulle prediking. Hulle spits hulle veral toe op die leerstukke op grond waarvan hulle afgeskei het, bv. Doop, Sabbat, Wederkoms, Die Heilige Gees, Apostelamp, ens. Prediking uit hierdie kringe is nie net anti-Kerk en anti-belydenisskrifte nie, maar by die Apostelsektes selfs anti-Bybels.

(b) Aangesien hulle die enigste „ware Kerk" wil wees, is hulle prediking daarop gemik om die ware godsryk binne die grense van die eie kring daar te stel.

(c) Prediking vanuit die sekte strominge beklemtoon veral Jesus die Wonderdoener. Die lidmaat moet sy eie redding vir alle wêreldse nood, siekte, kommer, ens. by die wonderdaener Jesus Christus vind.

\section{Algemene Gebeurtenisse :}

Algemene gebeurtenisse word voortdurend in die prediking aangehaal. Die wêreldoorloë, Driejarige-oorlog, Burgeroorlog, Depressie, droogtes, tornado's, verstedeliking van die platteland, industrialisasie en in die jongste tyd inflasie, verligtes, verkramp. tes en 'n hele reeks wat genoem kan word, oefen 'n invloed uit op die prediking.

Van ds. C. R. Kotzễ is 'n preekbundel uitgegee met die titel: Die Bybel en ons Volkstryd. Dit is ' $n$ mooi voorbeeld daarvan dat algemene gebeurtenisse die prediking voortdurend beïnvloed. 


\section{NUWE TENDENSE IN DIE PREDIKING}

\section{Social Gospel :}

Vanaf sekere kansels word daar 'n sosiale evangelie verkondig. Dit is 'n gebruik wat in die jongste tyd sterker na vore kom onder invloed van sekere politieke strominge bv. die sosialisme. Die Hiernamaals word sterk ingekort en die klem val op die huidige wêreld en teenswoordige lewe. Die tweede tafel van die wet word sentraal gestel en die Bergpredikasie van Jesus word oorbeklemtoon in die prediking. Die Verlosser van Wie die Skrif praat, is vir hierdie predikers 'n sosiale Hervormer, wat die volk verlos van sosiale onreg en onderdrukking. Die Opstanding van Jesus Christus het dan ook weinig betekenis. Let op die volgende aanhalings uit preke.

Uit „Everyman's road to Heaven” deur Leo J. Trese. „We must see too that the only certain path to heaven lies over the sometimes rugged but never impassable road of a good life."

"If we wish to test our closeness to Jesus and our oneness with Him, we have only to ask ourselves, 'How much concern do I feel for others? How much of myself do I devote to their needs?' "

Uit „Peace of soul" deur Fulton Sheen. „God is not hard to find, for He may be quickly discovered by reason, or by our strivings, or by His own gift . . God is the most obvious fact of human experience."

Uit „Out of Africa” deur Joost de Blank. „Christianity at its best has always jumped across the social and racial barriers."

„That so many thousands of Africans and Coloureds have remained faithful in spite of the discriminating legislation passed over the years is a miracle of no small magnitude - particularly when this discrimination is agreed by men who wish to be publicly known as devout and practising Christians."

Uit ,'n Boodskap in Suid-Afrika" deur Robert S. Bilheimer : "One thinks not only of unity among the churches as such, but of unity among Christians of different races and nations... Especially among the leadership of the churches there is a growing awareness that our unity in Christ transcends these barriers of nation and race."

Of die vraag wat hy op 'n ander plek stel: „Where complicated problems of economic and political justice are involved, what is the distinctive Christian contribution." 
„In my own country ... , we have seen the rise of the so-called social gospel ... In the ecumenical movement... we have paid a great deal of attention to the problems of church and society."

\section{Die V.V.O., Wêreldraad van Kerke en Ekumene :}

Opmerkinge in die prediking oor die V.V.O., wêreldraad van Kerke en Ekumene kom vanaf talle kansels, wisselend vanaf veroordeling tot propagering. Die offensiewe optrede van die Wêreldraad van Kerke en sy plaaslike kampvegters het 'n defensiewe reaksie ontketen.

In 1953 het prof. A. S. Geyser vir spreker die volgende in 'n proefpreek gedikteer: „Die organisasie van die V.V.O. meen die oplossing van alle probleme te vind in 'n onbekookte NeoHumanisme . . . Die bedreiging vir die Christendom is dat ons Christus wil vervang deur 'n sisteem, 'n wysgerige teorie of 'n politieke beskouing." En in ,Pro Veritate' van 15 Augustus 1963 maak hy hierdie opmerking: "If anything, the brotherhood in the flesh demands a visible and factual unity of the Christian Church in all the world and in all Africa." Met sy artikel in die H.T.S., April 1960 is hy ook verdediger van die Wêreldraad van Kerke.

Dr. A. J. G. Oosthuizen het in 1960 hierdie ware woord gespreek: „Daar was seker nog nooit 'n tyd in die geskiedenis van die Kerk, waarin die Kerk so getrou die eggo van die wêreldstem was soos vandag nie. Tae die V.V.O. sy deklarasie van menseregte uitreik, het die Kerk ook syne uitgereik. Natuurlik identies dieselfde, net in Bybelse taal. As die wêreld protesteer, protesteer die Kerk ook. As die wêreld swyg, is die Kerk ook stil of spreek so sag dat dit op 'n treeafstand onhoorbaar is."

In die prediking van die kampvegters vir die Wêreldraad van Kerke word daar klem gelê op sigbare eenheid van die Kerk wat bereik word deur die dienskneggestalte van die Kerk, die selfontlediging waartoe die Kerk bereid moet wees en die marteling wat onderneem behoort te word. Filipense 2:1-11, die dele van die Jesaja profesie wat handel oor die kneg van die Here, I Korinthiërs 1, I Johannes $1: 5-2: 11$, Math. $5:$ 14-16 ens. is geliefde skrifgedeeltes om te behandel.

Let op die volgende aanhalings uit preke van ds. Robert $\mathbf{S}$. Bilheimer, wat in Suid-Afrika gehou is :

“. . . our text forces us to reply that the Church is created in a certain form, that the form of the servant which Jesus took 
upon Himself is the proper characteristic and mark of the Church on earth."

"True Christian unity, therefore is the unity of the Servant. The Servant of the New Testament is the suffering servant . . . Thus the dead center of Christian unity is reached when a church empties itself, entering the suffering . . taking it into itself, transforming it and redeeming it."

"Far from considering his own happiness, his own security, his safety, he exposed himself and took the suffering of men upon himself and into himself. That is the attitude of selfemptying."

"The wisdom of the suffering servant is totally different. This wisdom understands that the most fundamental thing in life is not power, nor wealth, nor happiness nor anything else except suffering."

Uit die Wêreldraad van Kerke se Bybelstudie hierdie aanhaling :

„Hy het vir my gely, en om in sy lig te wandel beteken om ook te ly. Christus ly nog as mense ly, en ons word geroep om self daardie lyding te ondervind."

Vergelyk hier ook standpunte wat in „Pro Veritate" gestel word. Geen wonder dat verskillende persone hulleself graag 'n geestelike martelaarskap oplê nie.

\section{Besondere Prediking :}

Benewens die bestaande en feitlik algemeen aanvaarde kerklike jaar wat besondere tye en dae afsonder vir die behandeling van besondere stof, het daar in Suid-Afrika ook ander soorte van besondere prediking na vore gekom. In Suid-Afrika word daar op 16 Desember Geloftedag gevier. Die Ned. Herv. Kerk het spesifiek-afgesonderde Sondae as Dank- en Biddae vir die oes.

Die Ned. Geref. Kerk het spesifiek-afgesonderde Sondae vir 'n groot verskeidenheid van onderwerpe, bv. Week van gebed in die begin van die jaar, Biddag vir Kerkjeug, Wêreldbiddag vir vroue, Sinodale biddag en dankdag, Biddag vir studente, Biddae vir Dranksugtiges, Melaatse, Blindes, Dowes, Moeders, ens. By sulke spesiale dienste word nie net in die prediking oor die besondere onderwerpe gehandel nie, maar by sekeres ook offergawes opgeneem vir die spesifieke saak. 


\section{SLOT OPMERKINGS}

\section{Kanseltaal en Kanseltoon :}

Prediking word op verskillende maniere gelewer. Baie predikante gebruik geen of weinig kunsmatige middels om die luisteraars te boei en glo daaraan om rustig in helder en duidelike taal die evangelie te bring. Andersins vind ons predikers wat graag wil pronk met hulle kennis, geleerdheid en talente. Soms word die skraal inhoud van die preek verberg agter 'n opswepende manier van voordrag wat gepaard gaan met gesigsuitdrukkinge, beweginge en handgebare. Ek het selfs 'n preek op 'n oujaarsnag aangehoor wat met 'n kort tablo ingeskerp is. Daar is predikante wat 'n spesiale kanseltoon vir hulle stem het. Hulle stem op die kansel is totaal anders as die stem in die konsistorie. Die taal wat predikante op die kansels gebruik is oor die algemeen goed versorg en verhewe. Enkele predikers gebruik egter ook 'n plat taal wat meermale, veral in die vergelykings wat gemaak word, die luisteraars se lagspiere prikkel. Sommige waarhede word so gereeld met dieselfde woorde weergegee, dat dit reeds geykte uitdrukkinge in die Kerk geword het, vanweë oorbekendheid nie meer inslag neem nie en deur die jonger mense nie volledig begryp word nie.

\section{Preekbundels :}

Daar bestaan nie baie preekbundels nie - daar is seker ook nie 'n groot afset daarvoor nie. Feitlik alle preekbundels het 'n voorwoord waarin die skrywer sy werk met beskeidenheid uit gebrek aan ander bundels of op versoek van kennisse die wêreld instuur. As gevolg van hierdie beskeidenheid om die eie preke te publiseer, gaan vir die Kerk baie mense se harde werk oor jare heen verlore.

Voorts bestaan daar weinig lewensbeskrywings van predikante.

Op grond daarvan stel ek die ope vrae: Moet die predikante nie hulle eie preke sover moontlik op skrif bewaar vir die Kerk nie? Moet elke predikant dit nie so sien dat daar in die argief van die Kerk 'n spesiale plek is, waar sy studiewerk - veral sy preke bewaar moet word nie? Moet ons nie probeer om van mekaar 'n lewensbeskrywing te maak wat in die Kerkargief bewaar kan word nie? Wat sal die Kerk byvoorbeeld baie verloor as ons oor 'n 50-100 jaar verder niks meer het van 'n ds. D. F. Erasmus, dr. A. J. G. Oosthuizen, en andere nie. 


\section{GERAADPLEEGDE WERKE}

1. Hervormde Teologiese Studies - Oktober 1960.

2. Hervormde Teologiese Studies - April 1960.

3. 'n Boodskap in Suid-Afrika. Drie preke deur dr. P. S. Bilheimer.

4. Wêreldraad van Kerke: Konferensie Desember 1960. Bybelstudie.

5. PRO VERITATE - Mei 1962 tot Desember 1964.

6. Suid-Afrikaanse Kerkgeskiedenis - Prof. S. P. Engelbrecht.

7. Preeken van J. Murray - J. Murray.

8. Hoër lewe - Ds. Joh. Dreyer.

9. Bybelse Dagboek - Predikante en professore van die N.H. Kerk.

10. Oordenkings in Almanak van 1967.

11. Everyman's Road to Heaven - Leo. J. Trese.

12. Peace of Soul - Fulton Sheen.

13. Out of Africa - Joost de Blank.

14. Meditations on the Sunday Collects - H. P. Finis.

15. An Open Door - Leslie E. Stradling.

16. Een dertigtal leerredenen - D. Postma.

17. Tweede dertigtal leerredenen - D. Postma.

18. Enige nagelatene leerredenen - D. Postma.

19. Alles Genade - D. Postma.

20. Dwaling en Waarheid - Prof. dr. S. P. van der Walt.

21. Die vernaamste sektes in ons land - Ds. Jac. J. Möller.

22. De Openbare Eredienst der Nederl. Herv. Kerk in de 16de, 17de en 18de eeuw - Dr. G. D. J. Schotel.

23. Het Methodisme - J. D. du Toit.

24. Ds. S. J. du Toit: Weg en Werk - J. D. du Toit.

25. Die Gereformeerde Kerke onder die Kruis in Suid-Afrika Dr. J. A. S. Oberholster.

26. De Nasireer 'Gods - H. Ravesteyn.

27. De Gereformeerde Theologie - Dr. H. Visscher.

28. De Godsdienstoefeningen der Gereformeerden - Prof dr. S. D. van Veen.

29. De Evangelie prediking - Dr. A. W. Bronsveld.

30. Uit onszen Bloeityd - Dr. S. D. van Veen.

31. Calviyn als Bedienaar des Woords - P. Biesterveld.

32. Professor Dirk Postma - Dr. G. C. P. van der Vyver.

33. Vrede op Aarde - Ds. I. D. Kruger.

34. Het leven van Andrew Murray - J. du Plessis.

35. Afrikaansche Preken - F. L. Cachet.

36. Leerredenen - Ds. A. F. du Toit.

37. Die Boodskap van 'n Man - G. B. A. Gerdener.

38. Annale van die Universiteit van Stellenbosch - A. L. Geyer.

39. Verskillende preke van verskillende predikante. 